\title{
"PENELITIAN DAN PENGEMBANGAN" YANG BELUM DIMINATI DAN PERSPEKTIFNYA
}

Oleh:

\section{Dr. Yuberti, M. Pd.}

\section{PENDAHULUAN}

Perubahan paradigma perguruan tinggi dalam rangka menjawab kebutuhan tenaga kerja profesional yang dilandasi kemampuan akademik serta pengalaman dalam bidang keterampilan tertentu serta sikap positip terhadap profesi yang di embannya merupakan kebutuhan semua pihak. Pemerintah, sektor swasta, industri dan masyarakat pada umumnya, mempunyai harapan yang sama terhadap output dari setiap jenjang pendidikan. Mulai dari pendidikan dasar, menengah, sampai perguruan tinggi, diharapkan dapat menghasilkan individu-individu tidak hanya memiliki pengetahuan tetapi juga harus dapat mengiplementasikannya dalam kehidupan sehari-hari, paling tidak memberikan kebermaknaan bagi dirinya sendiri.

Persoalan selanjutnya adalah, bila kita lihat pada kenyataan di lapangan sebagian besar harapan tersebut belum tercermin dari setiap output jenjang pendidikan yang ada. Lantas pertanyaannya adalah, apa yang salah dengan sistem pembelajaran di sekolah, di perguruan tinggi, sampai kepada institusi-institusi pendidikan lainnya. Ironisnya perguruan tinggi, khususnya yang menyelenggarakan pendidikan untuk menghasilkan tenaga keguruan dan kependidikan mulai dari S1, S2 sampai S3 tidaklah sedikit jumlahnya. Lantas muncul pertanyaan berikutnya, apa yang salah dengan dengan hasil-hasil peneltian yang dilakukan, sehingga tidak dapat melakukan perubahan terhadap polapola pembelajaran yang ada. Bahkan untuk mencoba menggunakan hasil-hasil penelitiannya sendiripun, si peneliti tidak memiliki keberanian, karena ia tidak yakin dengan apa yang dilakukannya. Meskipun penelitian yang dilakukannya itu sudah mengikuti prosedur dan persyaratanpersyaratan penelitian yang berlaku di perguruan tingginya bahkan yang berlaku secara universal.

Akhirnya sampai pada pertanyaan yang kurang etis disampaikan, yaitu apa yang salah dengan metodologi-metodologi penelitian pendidikan yang banyak ditawarkan selama ini. Mulai dari beraneka ragam penelitian kuantitatif sampai kepada beraneka pilihan 
penelitian kualitatif. Seandainya tidak ada yang salah, mengapa hasil-hasil penelitian yang ada tidak berkontribusi positip terhadap peningkatan kualitas hasil belajar siswa di sekolah. Padahal pada saat ujian sebagian besar (di atas 90\%) menyatakan hasil penelitiannya berkontribusi secara positip terhadap peningkatan kualitas. Baik terhadap kualitas hasil belajar maupun terhadap sistem pengeloalaannya.

$$
\text { Ditengah keragaman }
$$

persoalan dan perdebatan terhadap ragam metodologi penelitian yang ada, muncul apa yang disebut dengan "Penelitian dan Pengembangan" yang seakan-akan barang baru, tetapi sesungguhnya stok lama. Dikatakan stok lama, karena "Penelitian dan Pengembangan" sudah lama digunakan di sektor industri yang menghasilkan produk, baik itu produk manufaktur, maupun produk olahan atau makanan. Hanya saja untuk penelitian dibidang pembelajaran, baru mulai dilirik belakangan ini.

Sebagai barang baru, ditengah berbagai ragam metode peneltian yang ada, kehadirannya tidak disambut "bak sebagai pahlawan", tetapi lebih cenderung "sebagai tamu yang mencurigakan". Tidaklah salah, bila ada yang menerima dan ada yang menolak secara halus, yang menerima karena mereka sadar benar akan manfaatnya dan yang menolak pada umumnya karena mereka belum jelas tentang manfaat dan praktek dari "Penelitian dan Pengembangan" dimaksud. Pertanyaan yang sering muncul dibenak mereka, ini penelitian atau pengembangan? Bila penelitian, dimana metodologinya, bila pengembangan apa produk yang dihasilkan? Lebih jauh lagi, apakah produk-produk yang dihasilkan mampu memberi jaminan terhadap peningkatan kualitas pembelajaran. Baik hasil belajar mahasiswa maupun peningkatan terhadap kualitas komponen pembelajaran lainnya. Dari berbagai persoalan yang diuraikan di atas, penulis ingin berkontribusi sedikit tentang diskriptif dari "Penelitian dan Pengembangan". Berlandaskan kejenuhan pengalaman dalam membimbing skripsi mahasiswa yang selalu dan selalu melakukan jenis Penelitian Tindakan Kelas (PTK) ataupun eksprimen/quasi eksprimen yang sejak lima tahun yang lalu. Semoga diskriptif dari "Penelitian dan Pengembangan” yang dipaparkan saat ini, dapat memberikan gambaran yang 
lebih jelas tentang “R\&D” dan berharap akan diminati mahasiswa.

\section{PEMBAHASAN}

\section{Apa itu "Penelitian dan} Pengembangan"

Secara sederhana "Penelitian
dan Pengembangan" defenisikan sebagai metode penelitian yang bertujuan untuk mencaritemukan, memperbaiki, mengembangkan, menghasilkan produk, menguji produk, sampai dihasilkannya suatu produk yang terstandarisasi sesuai dengan indikator yang ditetapkan. Atau dengan kata lain sebagai metode penelitian yang bertujuan" menghasilkan suatu produk unggulan" yang didahului "penelitian pendahuluan" sebelum produk dikembangkan. Hal ini dilakukan untuk memastikan, bahwa produk yang akan dikembangkan adalah benar-benar produk yang dibutuhkan. Oleh karena itu "Penelitian dan Pengembangan" banyak digunakan disektor industri dalam rangka menghasilkan produkproduk unggulan, baik itu industri manufaktur maupun industri olahan atau makanan

Tidak heran bila kita menemukan banyak sekali defenisi yang diberikan terhadap "Penelitian dan Pengembangan" ini. Namun dalam makala ini kita tidak membicarakan defenisi-defenisi yang ada, tetapi akan lebih fokus pada defenisi"Penelitian dan Pengembangan" di bidang pendidikan saja. Borg \& Gall (2003), dalam bukunya "Educational Research", menjelaskan bahwa "Penelitian dan Pengembangan" dalam pendidikan adalah model pengembangan berbasis industri dimana temuan hasil penelitiannya digunakan untuk merancang produk pembelajaran, yang kemudian secara sistematis diuji cobakan dilapangan, dievaluasi, dan disempurnakan sampai dihasilkannya suatu produk pembelajaran yang memenuhi standarisasi tertentu, yaitu efektif, efisien, dan berkualitas.

Efektif, adalah ukuran terhadap keunggulan produk dalam mencapai tujuan/kompetensi pembelajaran sesuai dengan kriteria/indikator atau standar ketuntasan belajar yang telah ditetapkan sebelumnya oleh sekolah, lembaga, atau pemerintah. Oleh karena itu dalam menentukan kriteria/indikator atau standar ketuntasan perlu dilakukan secara cermat dan terukur. Untuk itu perlu ada penelitian pendahuluan agar apa yang telah ditetapkan merupakan 
target yang realistis sesuai dengan kebutuhan.

Efisien, artinya bahwa produk yang dikembangkan mampu memberikan jaminan bahwa dari segi waktu, biaya, dan tenaga yang diperlukan untuk mencapai tujuan/kompetensi pembelajaran tertentu lebih singkat, lebih murah, dan lebih ringan bila dibandingkan dengan menggunakan produk-pruduk pembelajaran sebelumnya.

Berkualitas, artinya bahwa produk yang dikembangkan harus memenuhi standar industri dari berbagai aspeknya. Selain itu satu hal yang harus diperhatikan dari aspek kualitas selain memenuhi standar industri adalah keamanan dalam menggunakan produk tersebut dan tidak berbahaya terhadap kesehatan pengguna.

Selanjutnya apa yang dimaksud dengan produk instruksional dalam "Penelitian dan Pengembangan" menurut Borg \& Gall dalam "Educational Research" (1989), tidak hanya terbatas pada buku dan filmfilm instruksional atau jenis media lainnya, tetapi juga meliputi metode, strategi pembelajaran, model pembelajaran, bahkan sampai pada program-program pengembangan lainnya. Sedangkan yang dimaksud dengan "program" adalah "sistem belajar yang lengkap", termasuk didalamnya bahan belajar yang dikembangkan serta bahan-bahan penyerta lainnya; seperti panduan penggunaan bagi guru dan panduan belajar bagi siswa, serta set instrumen pengukuran ketercapaian tujuan pembelajaran.

\section{Model "Penelitian dan Pengembangan"}

Dari banyak model-model "Penelitian dan Pengembangan" yang ada, yang secara khusus mengarahkan penelitian dan pengembangan di bidang pendidikan, khususnya pembelajaran adalah model R\&D yang dikembangkan oleh Borg dan Gall. Model ini dikenal dengan model sepuluh langkah. Berikut ini adalah kesepuluh langkah utama penelitian dan pengembangan yang dikemukan oleh Borg \& Gall (1989). 


\section{RESEAROH and $R_{\text {\& }} \mathrm{D}$ DEVELOPMENT}

LANGKAH UTAMA DALAM R\&D

Melakukan penelitian pendahuluan

Melakukan perencanaan

Mengembangkan produk awal

10 ․ Uji coba, lapangan tahap awal

Melakukan revisi produk utam

Uji coba lapangan utama

Melakukan revisi produk operasiona

Uji coba lapangan operasional

Menukan revisi produk akhir

Sepuluh langkah utama dalam penelitian dan pengembangan Borg \& Gall (2003)

Sesungguhnya kesepuluh dan pengembangan dalam bidang langkah utama yang dikemukakan pendidikan yang sesungguhnya Borg \& Gall, bila bandingkan adalah langkah-langkah yang dengan sepuluh langkah dalam terdapat dalam Model model pengembangan sistem Pengembangan Instruksional yang instruksional yang dikemukakan oleh Dick and Carey memiliki kesamaan dalam kerangka berpikirnya. Bahkan Borg \& Gall (2003), mengatakan dikembangkan oleh Dick \& Carey. Berikut ini adalah langkahlangkah pengembangan instruksional Dick \& Carey.

bahwa langkahlangkah penelitian

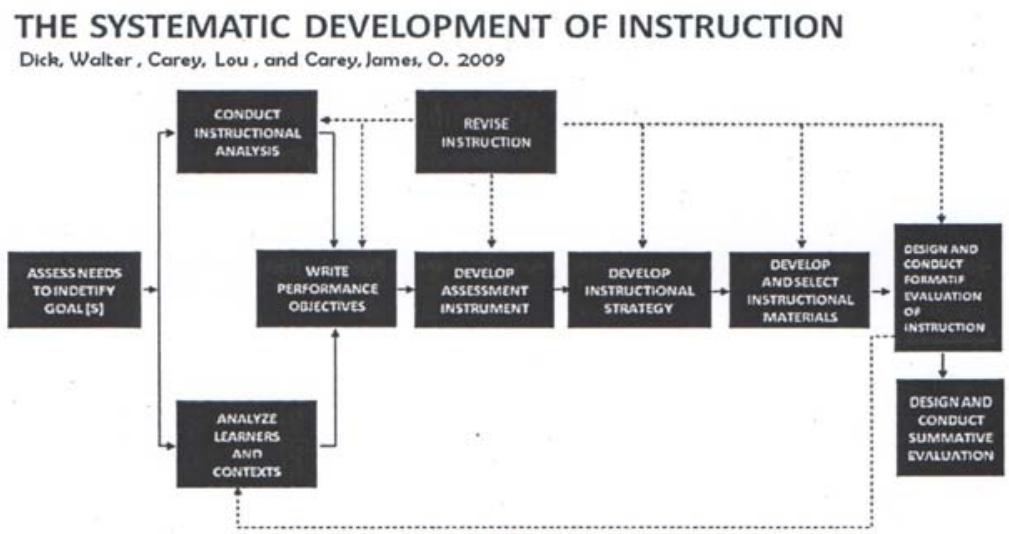

Satu hal yang menarik, Borg \&

Gall menyadari betul bahwa setiap langkah pengembangan yang terdapat dalam model Dick \& Carey 
adalah satu prosedur yang sangat sistematis bila dibandingkan dengan model-model pengembangan instruksional lainnya. Hanya saja pada model Dick \& Carey ditahap awal pengembangannya dimulai dengan "assessment" bukan "research", yang dari segi cakupan masalah agak berbeda, sebab cakupan "assessment" lebih sempit dari "research". Akan tetapi bila fokus masalahnya sudah jelas dan merupakan masalah yang sifatnya berulang (sudah dikenali), maka model pengembangan Dick \& Carey dapat digunakan seutuhnya sebagai metodologi dalam "Penelitian dan Pengembangan" dibidang pendidikan, khususnya pengembangan produkproduk instruksional. Dalam konteks ini, model Dick \& Carey, bukan lagi hanya sebagai model pengembangan instruksional, akan tetapi sebagai metodologi dalam "Penelitian dan Pengembangan". Bila keberadaannya sebagai metodologi, maka satu hal yang harus dilakukan adalah "peneliti harus taat dan konsisten mengikuti tahap demi tahap yang terdapat dalam model Dick \& Carey.

\section{Model Dick \& Carey sebagai metodologi "Penelitian dan Pengembangan" Mengapa model Dick \&} Carey, bukan model pengembangan instruksional lainnya? Ini adalah pertanyaan yang sering dilontarkan oleh mereka yang ingin melakukan penelitian dan pengembangan dalam bidang pengembangan produk instruksional atau produk pembelajaran. Borg \& Gall, (2003) dalam bukunya "Educational Research" mengatakan, karena model Dick \& Carey adalah suatu model pengembangan instruksional yang sangat sistematis. Mulai dari tahap awal pengembangan sampai kepada desiminasi produk yang dikembangkan dengan melakukan proses perbaikan yang berlangsung secara terus menerus hingga target (standar kualitas) produk yang dikembangkan tercapai, yaitu (efektif, efisien, dan berkualitas). Ini adalah tahapan pengembangan instruksional yang tidak dimiliki oleh model pengembangan instruksional lainnya. Pertanyaan berikutnya adalah, apakah cakupan "penelitian pendahuluan" yang dimaksud oleh Borg \& Gall identik dengan "identifikasi kebutuhan" yang terdapat pada langkah awal model 
Dick \& Carey? Tentu, tidak.

Penggunaan model Dick \& Carey sebagai metodologi dalam "Penelitian dan Pengembangan" secara utuh, bila masalah yang akan dipecahkan sudah jelas dan fokus. Misalnya masalah yang berulang atau sering terjadi, seperti siswa selalu mengalami kesulitan menangkap pesan pembelajaran bila guru tidak menggunakan media untuk menjelaskan materi tertentu. Akan tetapi bila menggunakan media siswa dapat memahaminya dengan balk. Dalam hal seperti ini, guru mengetahui secara pasti bahwa penyebab kesulitan siswa dalam pembelajaran adalah kurangnya media yang mendukung proses pembelajaran. Untuk masalah yang demikian Model Dick \& Carey dapat digunakan secara utuh sebagai metodologi dalam "pengembangan dalam produk".

Berbeda halnya bila masalah yang ditemukan bersifat kompleks dan umum sangat umum. Misalnya, nilai rata-rata siswa untuk mata pelajaran $\mathrm{X}$ secara nasional atau perwilayah 5,0. Jauh dari standard ketuntasan minimal yang ditetapkan oleh pemerintah, misalnya 7,50. Untuk masalah yang demikian dengan "need assessment" atau identifikasi kebutuhan saja tidaklah mampu untuk mengenali penyebab tidak tercapainya ketuntasan belajar yang ditetapkan. Dalam hal ini, Borg \& Gall mengatakan perlu adanya penelitian pendahuluan untuk mengetahui permasalahan atau penyebab tidak tercapainya ketuntasan belajar yang telah ditetapkan. lnilah inti dari penelitian pendahuluan, yaitu untuk menentukan secara pasti penyebab atau masalah yang akan dipecahkan.

Dari ilustrasi di atas untuk mendapatkan informasi yang akurat atau tepat haruslah dilakukan melalui metode penelitian tertentu, misalnya survey atau metode lainnya. Oleh karena itu, peneliti perlu mengembangkan set instrument penelitian pendahuluan sebelum turun mengumpulkan data. Data yang akurat hanya dapat diperoleh melalui instrument yang baik dan valid. Bila demikian model Dick \& Carey tidak dapat digunakan sepenuhnya sebagai metodologi dalam "Penelitian dan 
Pengembangan" yang bersifat

kompleks. Ada baiknya, bila

peneliti menggabungkan dua

metodologi dalam satu rentang

penelitian, seperti terlihat pada

model berikut ini.

MODEL PENELITIAN DAN PENGEMBANGAN

KOMBINASI BORG \& GALL DENGAN DICK \& CAREY

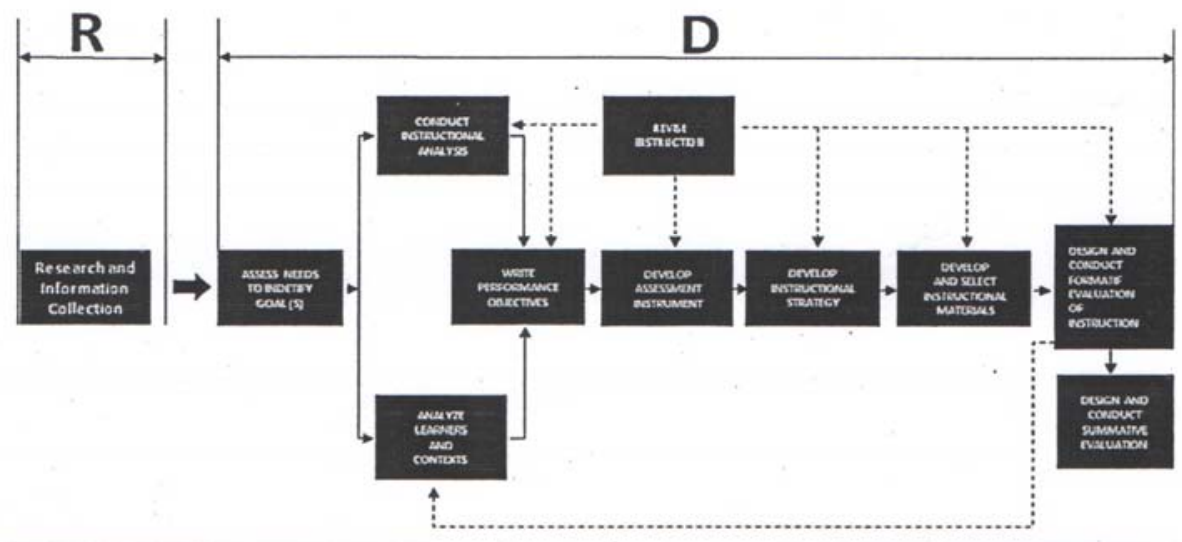

Borg \& Gall

Dick \& Carey

Model “Penelitian dan Pengembangan”gabungan Borg \& Gall dan Dick \& Carey

Dari model di atas, model pengembangan instruksional

Dick \& Careydigunakan setelah diperoleh data atau infomasi yang pasti mengenai penyebabtidak tercapainya ketuntasan belajar yang ditetapkan; yaitu melalui penelitian pendahuluan Borg \& Gall. Tidak tertutup kemungkinan "Penelitian dan Pengembangan' ke depan akan mengkombinasikan berbagai model pengembangan instruksional yang ada sebagai metodologi dalam "Penelitian dan Pengembangan". Misalnya Model Pengembangan lnstruksional" atau yang dikenal dengan model MPI. Model MPI adalah model yang dikembangkan oleh Atwi Suparman. Model MPI ini 
merupakan modifikasi dari Model Dick \& Carey. yang disesuaikan dengan kondisi dan iklim sistem pendidikan nasional kita. Berdasarkan pengalaman penulis, model MPI jauh lebih fleksibel dan rasional dari pada model Dick \& Carey bila diterapkan untuk pembelajaran klasikal di semua jenjang pendidikan formal, mulai dari pendidikan dasar sampai pendidikan tinggi, maupun dipendidikan non formal.

Selain itu model MPI juga dapat digunakan untuk mengembangkan berbagai produk pembelajran, baik yang berorientasi pada sistem, pada produk media pembelajaran, maupun yang beroriantasi pada kelas. Namun satu hal yang perlu diperhatikan, bila suatu model pengembangan instruksional sudah menjadi suatu metodelogi dalam "Penelitian dan Pengembangan” maka peneliti harus taat azas terhadap prosedur yang ada pada model tersebut. Sama halnya seperti kita mentaai prosedur dari metodelogi penelitian lainnya.

\section{Konsep Pengembangan Model}

Secara umum model dimaknai sebagai objek atau konsep yang digunakan untuk merepresentasikan sesuatu hal. Pemahaman model dalam penelitian mengacu pada definisi yang diungkapkan oleh Miarso bahwa model adalah representasi suatu proses dalam bentuk grafis dan/atau naratif, dengan menunjukkan unsur-unsur utama serta strukturnya.

Dalam hal ini dimungkinkan penafsiran model naratif ke dalam bentuk grafis, atau sebaliknya. Menurut Miarso, ada berbagai karakteristik model pengembangan instruksional, di antaranya adalah beracuan tujuan, keserasian tujuan, sistematik dan berpedoman pada evaluasi.

Banyak model pengembangan yang telah di keluarkan oleh ahlinya. Namun tidak semua model itu serupa dan sesuai digunakan untuk memecahkan masalah. Suparman menjelaskan beberapa model-model yang telah digunakan oleh pendiri dan orang lain seperti system approach for education (SAFE), Michigan state University Instructional systems development model, Project Minerva instructional systems design, 
teaching research system dan banathy instructional development system.

Bila diperhatikan kelima model tersebut maka terdapat istilah-istilah yang berbeda yang mereka gunakan kemudian terdapat urutan langkah-langkah yang ditempuh juga tidak selalu sama. Ini menunjukkan bahwa proses pengembangan instruksional itu tidak terdiri atas urutan langkahlangkah yang baku, atau yang tidak dapat ditawar lagi. Setiap model bertujuan untuk menghasilkan suatu sistem instruksional. Prosedur yang mirip digunakan antara satu dengan yang lain, tetapi mereka menggunakan penjelasan urutan dan bahasa yang tidak selalu sama. Beberapa contoh model pengembangan yang sering digunakan oleh pengembang instruksional adalah model Dick and Carry.

Prinsip yang menjadi acuan dalam mengembangkan model pembelajaran berbasis otak ini mengacu pada pandangan Miarso yang diuraikan sebagai berikut (1) prinsip kemandirian. Hal ini diwujudkan dengan adanya paket pembelajaran berbasis otak dalam mata pelajaran IPA yang dapat dipelajari oleh guru (2) prinsip keluwesan. Hal ini diwujudkan dengan dimungkinkannya guru untuk memvariasikan metode, media dan gaya mengajar dalam proses pembelajaran sesuai dengan kebutuhan peserta didik; (3) prinsip keterkinian. Hal ini diwujudkan dengan tersedianya paket pembelajaran; (4) prinsip kesesuaian. Hal ini diwujudkan dengan adanya program belajar yang terkait langsung dengan kebutuhan pribadi dan keunikan masing-masing peserta didik; (6) prinsip efisiensi. Hal ini diwujudkan dengan pendayagunaan berbagai macam sumber belajar yang tersedia dengan seoptimal mungkin.

Salah Satu Kerangka
model pembelajaran yang
dikembangkan berdasarkan pada
kerangka teori pembelajaran
Reigeluth dan Merrill yang
dapat terlihat pada gambar
berikut;


Instruksional

Conditions

Instructional

Methods

Instructional

Outcomes

\begin{tabular}{lrr}
\hline $\begin{array}{l}\text { Subjek Matter Characteristich } \\
\text { Goals }\end{array}$ & Contrainst & Student \\
Characteristics
\end{tabular}

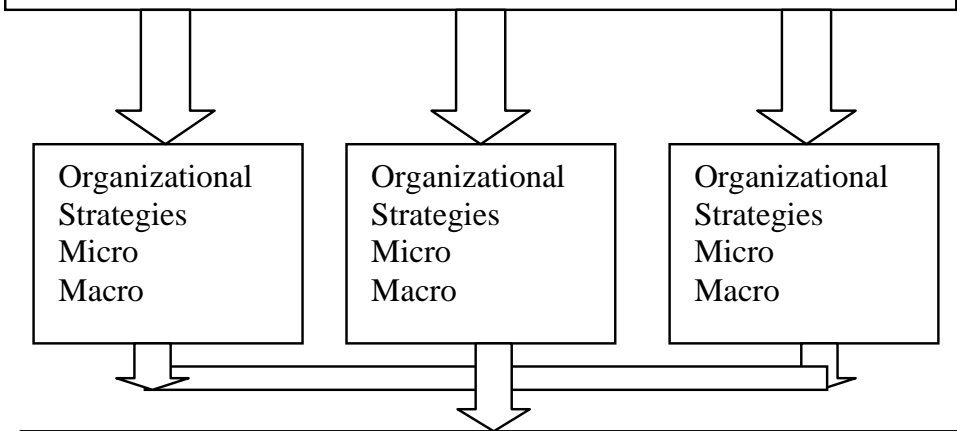

Effectiveness

Efficiency

Appeal of the Instruction

Gambar 1. Model Reigeluth

Model Reigeluth ini dengan media, dan bentuk

menggambarkan bahwa ada 3 (tiga)

komponen utama yang harus

diperhatikan dalam pengembangan

model pembelajaran, yaitu: (1)

kondisi pembelajaran, meliputi: (a)

karakteristik pelajaran, yang mencakup: tujuan pembelajaran dan

karakteristik pelajaran IPA; (b)

karakteristik guru; (2) metode

pembelajaran, meliputi: (a) strategi

pengorganisasian bahan pelajaran,

mencakup antara lain bagaimana

merancang bahan untuk keperluan

belajar; (b) strategi penyampaian

mencakup antara lain: media

pembelajaran, interaksi pembelajar pembelajaran yaitu 1) kegiatan pra

pembelajaran, 2) kegiatan pembelajaran/ penyampaian materi, dan 3) prosedur kegiatan pembelajaran; $\quad$ (c) strategi pengelolaan pembelajaran mencakup antara lain: 1) penjadualan penggunaan strategi pembelajaran; 2) pembuatan catatan kemajuan belajar peserta didik; 3) pengelolaan motivasional; dan (3) pengembangan prosedur pengukuran hasil pembelajaran mencakup: (a) efektivitas; (b) efisiensi; (c) daya tarik pembelajaran. 
Ada sejumlah model pengembangan pembelajaran. Model-model tersebut berbeda satu sama lainnya. Namun semuanya mengandung tiga tahap, yaitu mengidentifikasi, mengembangkan dan mengevaluasi atau merevisi. Perbedaan antara model yang satu dengan yang lain terletak pada empat faktor, yaitu: tingkat penggunaan, penggunaan istilah, jumlah langkah pada setiap tahap, dan lengkap tidaknya konsep dan prinsip yang digunakan. Tahap analisis dan desain terdiri dari analisis kebutuhan, perumusan tujuan umum, analisis pembelajaran, analisis pengetahuan awal peserta didik, perumusan tujuan khusus, penentuan pokok-pokok isi pelajaran. Sementara tahap pengembangan meliputi pemilihan strategi pembelajaran yang terdiri atas urutan pembelajaran, pemilihan metode pembelajaran, pemilihan media dan penentuan waktu, pengembangan bahan belajar dan pengembangan buku panduan. Sedangkan tahap evaluasi mencakup pengembangan alat evaluasi, uji coba dan revisi.

Operasionalisasi penelitian ini, digunakan prosedur yang diformulasi dari Borg and Gall, yaitu: Tahapan Pendahuluan: (1) studi pendahuluan; Tahapan Pengembangan: (2) perencanaan, (3) produksi tahap awal, (4) uji coba awal, (5) revisi produk utama, (6) uji coba lapangan utama, (7) revisi produk operasional, (8) uji lapangan operasional, (9) revisi produk final; Tahapan Implementasi: menetapkan Model yang akan digunakan.

5. Batasan "Penelitian dan Pengembangan"

Hasil "Penelitian dan Pengembangan" adalah berbagai produk instruksional yang berorientasi pada sistem/model pembelajaran, pada bahan pembelajaran, maupun yang berorientasi pada kebutuhan satuan pelajaran. Lantas muncul pertanyaan tentang kepantasan cakupan "Penelitian dan Pengembangan" bagi strata pendidikan yang berbeda, mulai dari S1, S2, sampai kepada S3. Sebab secara metodologis metode penelitian dan pengembangan, tahapannya adalah sama untuk semua jenjang. Artinya semua akhir 


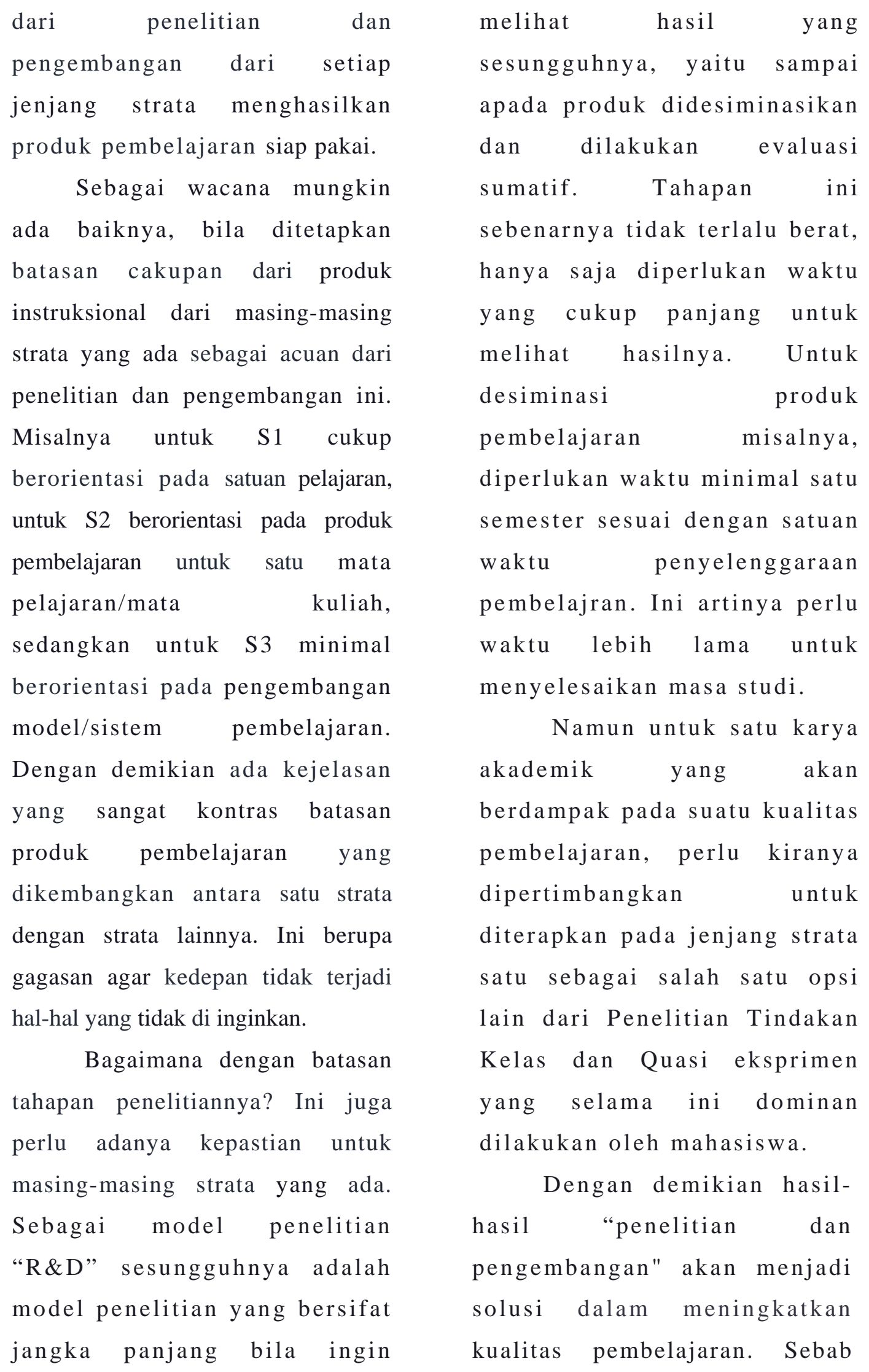


setiap hasil dari "Penelitian dan Pengembangan" merupakan produk inovatif yang memberi jaminan terhadap pencapaian tujuan/kompetensi pembelajaran dari setiap mata pelajaran yang dikembangkan.

\section{KESIMPULAN}

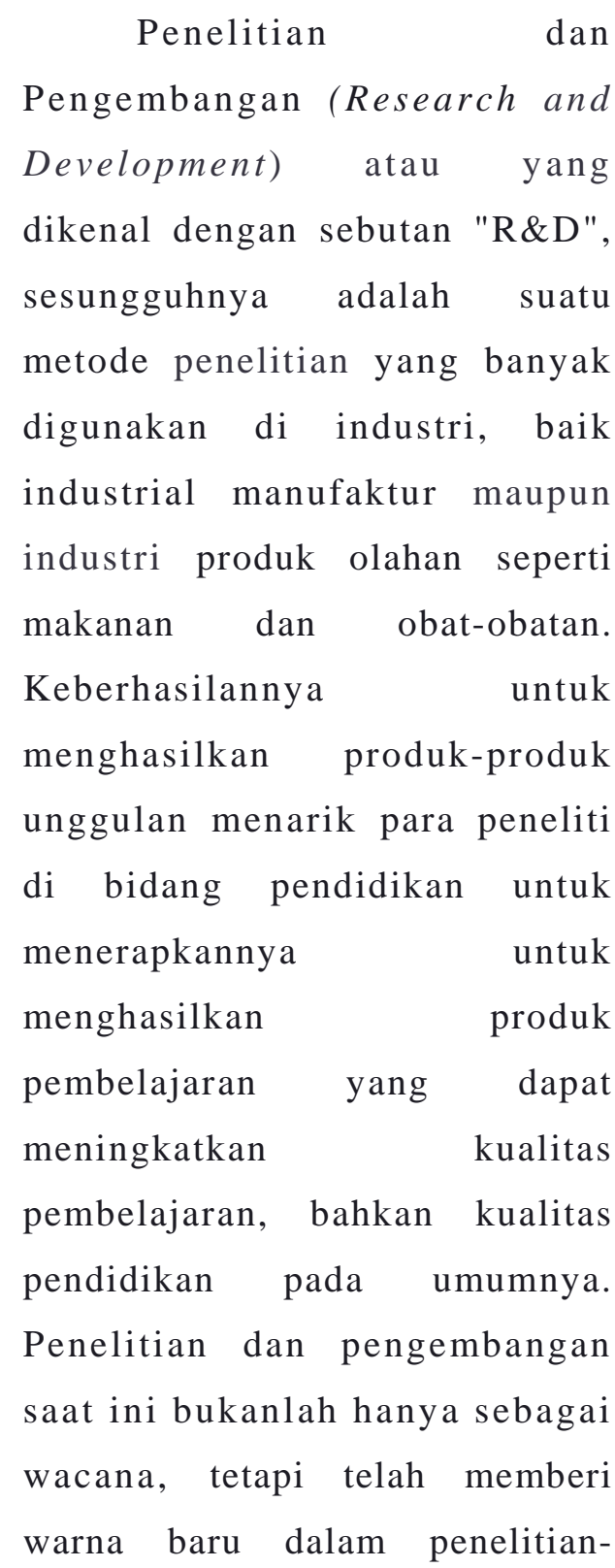

penelitian pendidikan, dengan harapan, setiap hasil dari "Penelitian dan Pengembangan" akan. Memberikan sumbangan yang positip terhadap peningkatan kualitas pembelajaran di semua jenjang pendidikan yang ada. Sebagai model penelitian yang berorientasi pada pengembangan produkpembelajaran yang inovatif, diharapkan akan dapat memberi banyak ragam cara belajar yang dapat dipilih peserta didik sesuai dengan kebutuhannya. Hanya saja kedepan semua institusi pendidikan yang melakukan "Penelitian dan Pengembangan" perlu mengembangkan sistem database untuk menghindari pengembangan produk pembelajaran yang tumpang tindih. 


\section{DAFTAR PUSTAKA}

Reigeluth, Charles M. (Ed),

Dick, Walter dan Carey, Lou. The Systematic Design of Instruction. Palo Alto, California, Scott: Foreman and Company, 1996.

Gall, Meredith D.Gall Joyce P. \& Borg, Walter R. Educational Research An Introduction, Seventh Edition. Boston: Pearson Education Inc, 2003.

Miarso, Yusufhadi. Menyemai Benih Teknologi Pendidikan. Kencana Jakarta, 2005
Instructional Design, Theories and Models: An Overview of Their Current Status, New Jersey: Lawrence Erlbaum Associates Publishers, 1983.

Suparman, M. Atwi. Desain Instruksional, Jakarta: Pusat Penerbit Universitas Terbuka, 2004. 